The Student Lovers 
PALI LANGUAGE TEXTS: CHINESE

Social Sciences and Linguistics Institute University of Hawai' $i$

John DeFrancis

Editor 


\title{
The Student Lovers
}

\author{
KRISTINA LINDELL
}

University of Hawai'i Press

Honolulu 
Copyright () 1975 by The University Press of Hawaii All rights reserved

Library of Congress Catalog Card Number 70-189615 ISBN 0-8248-0225-X

Printed in the United States of America

$\begin{array}{llllllllllll}07 & 06 & 05 & 04 & 03 & 02 & 9 & 8 & 7 & 6 & 5 & 4\end{array}$

University of Hawai $i$ Press books are printed on acidfree paper and meet the guidelines for permanence and durability of the Council on Library Resources. 